\title{
FAKTOR-FAKTOR YANG BERHUBUNGAN DENGAN KEKAMBUHAN PADA PASIEN SKIZOFRENIA DI KABUPATEN BADUNG
}

\author{
Ni Putu Gita Antari*, Ni Luh Putu Suariyani \\ Program Studi Sarjana Kesehatan Masyarakat Fakultas Kedokteran Universitas Udayana \\ Alamat: Jalan PB. Sudirman, Denpasar, Bali 80232
}

\begin{abstract}
ABSTRAK
Skizofrenia merupakan penyakit yang berpotensi tinggi menimbulkan kekambuhan. Kekambuhan skizofrenia mengakibatkan $72 \%$ penderita skizofrenia tidak mampu bekerja, $69 \%$ direhospitalisasi, 22\% melakukan percobaan bunuh diri, dan $20 \%$ dipasung. Tujuan penelitian ini untuk mengetahui faktor-faktor yang berhubungan dengan kekambuhan pada pasien skizofrenia di Kabupaten Badung. Jenis penelitian ini adalah observasional analitik dengan desain Crossectional. Penelitian ini dilakukan di Poliklinik Jiwa Puskesmas I Abiansemal dan RSUD Mangusada pada Januari-Juni 2020. Sampel dalam penelitian ini adalah pasien skizofrenia yang melakukan pengobatan di lokasi penelitian. Teknik sampling menggunakan Simple Random Sampling dengan jumlah sampel 112 sampel. Data dianalisis secara Univariat, Bivariat dan Multivariat. Hasil penelitian menunjukkan proporsi pasien skizofrenia mengalami kekambuhan sebesar 35,71\%. Variabel yang berhubungan dengan kekambuhan pasien skizofrenia di Kabupaten Badung yaitu dukungan keluarga ( $\mathrm{p}=0,0308$; PR:1,86; 95\% CI:1,13-3,06), kepatuhan minum obat ( $\mathrm{p}=0,0120 ;$ PR:1,87; 95 CI:1,16-3,03), tingkat pendidikan ( $\mathrm{p}=0,0004 ; \mathrm{PR}: 2,89 ; 95 \% \mathrm{CI}: 1,47-5,69)$, dan status pekerjaan ( $\mathrm{p}=0,0014$; PR:4,11; 95\% CI:1,37-12,30). Variabel yang paling berhubungan dengan kekambuhan pasien skizofrenia yaitu tingkat pendidikan (OR:8,9). Dapat disimpulkan terdapat hubungan antara dukungan keluarga, kepatuhan minum obat, tingkat pendidikan, dan status pekerjaan. Sebagai upaya mencegah kekambuhan, keluarga pasien skizofrenia diharapkan lebih memperhatikan faktor-faktor yang dapat menyebabkan terjadinya kekambuhan pasien skizofrenia.
\end{abstract}

Kata Kunci: Skizofrenia, Kekambuhan, Dukungan Keluarga, Kepatuhan Minum Obat, Jarak Tempat Tinggal dengan Pelayanan Kesehatan Jiwa

\begin{abstract}
Schizophrenia is a disease that potentially results of relapse. $72 \%$ patients with relaps schizophrenia causes inability to work, $69 \%$ is re-hospitalised, $22 \%$ attempted suicide, $20 \%$ are put into the stock. This study aims to describe the factors that related to the relapse of schizophrenia patients in Badung Regency. This study is observational analytic with crossectional design. This study done in Poliklinik Jiwa Puskesmas I Abiansemal and RSUD Mangusada in January-June 2020. Sample of this study were patients with schizophrenia disease that came to research area. Used Simple Random Sampling technique with 112 samples. Univariat, Bivariat, and Multivariat Analysis used in analysing data. The results showed $35.71 \%$ of schizophrenia patients had relapse. Variables were related to relapse of schizophrenia patients were family support ( $\mathrm{p}=0,0308$; PR:1,86; 95\%CI:1,13-3,06), medication adherence ( $\mathrm{p}=0,0120$; PR:1,87; 95\%CI:1,16-3,03), education level ( $\mathrm{p}=0,0004 ;$ PR:2,89; 95\%CI:1,47-5,69), and employment status ( $\mathrm{p}=0,0014 ; \mathrm{PR}: 4,11 ; 95 \% \mathrm{CI}: 1,37-12,30)$. Variable most associated with relapse in schizophrenic patients is level of education (OR:8,9). It can concluded that factors related to relapse in schizophrenia patients in Badung Regency are family support, medication adherence, education level, and employment status. In effort to prevent relapse, schizophrenia patients' families are expected to pay more attention to factors that can cause schizophrenia patients to recur.

Keywords: Schizophrenia, Relapse, Family Support, Medication Adherence, The Distance of Their Home's with Psichiatry Clinic
\end{abstract}

\section{PENDAHULUAN}

Skizofrenia merupakan salah satu gangguan jiwa yang menjadi tren belakangan ini. Skizofrenia adalah kumpulan gejala atau sindrom yang dapat menyebabkan masalah kejiwaan yang

Email korespondensi: suar_chp@yahoo.com sangat serius, yang ditandai dengan adanya halusinasi atau gangguan persepsi sensori, waham atau delusi, gangguan pada pikiran, pembicaraan dan perilaku serta emosi yang tidak sesuai (Wardani dan Dewi, 2018; Yusuf, et al., 2019). Skizofrenia 
dipengaruhi oleh berbagai faktor, diantaranya umur, jenis kelamin, status pekerjaan, psikososial, status ekonomi, pendidikan, daerah tempat tinggal dan riwayat keturunan (Wahyudi dan Fibriana, 2016; Zahnia dan Sumekar, 2016; Sudarmono et al., 2018). Menurut data WHO pada tahun 2016, di dunia terdapat sekitar 21 juta orang terkena skizofrenia (Prsityantama dan Ranimpi, 2018). Skizofrenia juga menjadi salah satu permasalah kesehatan Indonesia. Menurut Hasil Riset Kesehatan Dasar tahun 2018, proporsi gangguan jiwa skizofrenia di Indonesia sebesar 7 per mil, terjadi peningkatan dibandingkan tahun 2013 sebesar 1,7 per mil. Pada tahun 2018, Provinsi Bali menempati urutan pertama dengan proporsi skizofrenia tertinggi di Indonesia, yaitu sebesar 11 per mil dan terjadi peningkatan dibandingkan tahun 2013 yaitu sebesar 2,3 per mil (Kementrian Kesehatan RI, 2018). Berdasarkan data dari Dinas Kesehatan Provinsi Bali, adapun jumlah pasien skizofrenia di Provinsi Bali pada tahun 2018 yaitu sebanyak 3.754 pasien, dimana terbanyak terdapat pada Kabupaten Tabanan, Klungkung, Buleleng, Denpasar, Badung, Jembrana, Bangli Gianyar, dan Karangasem. Kabupaten Badung merupakan daerah yang tergolong maju dan memiliki pertumbuhan yang cepat dengan pendapatan asli daerah tertinggi di Provinsi Bali (Dewi, Budhi dan Sudirman, 2014). Meskipun demikian, penderita skizofrenia di Kabupaten Badung dapat dikatakan masih tinggi. Hal tersebut dapat dilihat dari data Program Kesehatan Jiwa Dinas Kesehatan Kabupaten Badung yang menunjukkan adanya peningkatan yang signifikan, dimana pada tahun 2018 Email korespondensi: suar_chp@yahoo.com jumlah pasien skizofrenia di Kabupaten Badung adalah sebanyak 339 pasien, sedangkan tahun 2019 yang terhitung sampai bulan November terdapat sebanyak 554 pasien skizofrenia.

Skizofrenia merupakan penyakit yang berpotensi tinggi untuk menimbulkan kekambuhan. Kekambuhan (relapse) adalah suatu kondisi dimana munculnya kembali tanda dan gejala suatu penyakit penyakit setelah mereda (Fadli dan Mitra, 2013). Penelitian yang dilakukan di Hongkong menemukan bahwa dari 93 pasien skizofrenia masingmasing memiliki potensi kekambuhan sebesar $21 \%$, 33\%, dan $40 \%$ pada tahun pertama, kedua, dan ketiga (Hui, 2011). Kekambuhan pada pasien skizofrenia menjadi permasalahan yang serius. Hal tersebut dikarenakan kekambuhan menyebabkan $72 \%$ orang dengan skizofrenia tidak mampu bekerja, 69\% direhospitalisasi, 22\% melakukan percobaan bunuh diri, dan 20\% dipasung (Christy dan Westa, 2019). Penelitian yang dilakukan di Tanzania tahun 2014 menyebutkan bahwa faktor resiko yang menyebabkan tingginya frekuensi kekambuhan pasien skizofrenia adalah keluarga dan lingkungan yang kurang mendukung, ketidakpatuhan pasien dalam minum obat, tersedianya fasilitas kesehatan, jarak tempat tinggal dan kemudahan menjangkau fasilitas pelayanan kesehatan jiwa, serta keadaan sosial ekonomi, serta diri pasien sendiri (Sariah, Outwater dan Malima, 2014).

Keluarga merupakan lingkungan terdekat dan memiliki peran penting dalam kehidupan pasien skizofrenia. Daya dukung keluarga yang buruk dapat berpengaruh pada pasien skizofrenia 
sehingga memiliki peluang 6 kali lipat mengalami kekambuhan dibandingkan keluarga yang memiliki dukungan baik (Pratama, Syahrial dan Ishak, 2015). Selain dukungan keluarga, kepatuhan minum obat juga berperan dalam kekambuhan pada pasien skizofrenia. Kepatuhan minum obat memang tidak dapat menyembuhkan dan tidak mengurangi kekambuhan 100 persen, namun dengan perilaku patuh minum obat maka waktu remisi pasien skizofrenia setahun lebih lama dan gejala psikosis yang muncul tidak akan terlalu parah (Nurjamil dan Rokayah, 2019).

Dalam upaya memberikan pengobatan yang optimal dan mencegah kekambuhan pada pasien skizofrenia tentu saja terdapat beberapa kendala. Salah satu kendala dalam pengobatan skizofrenia adalah keterlambatan pasien datang ke pelayanan kesehatan jiwa, dimana hal tersebut dapat berakibat buruk dan dapat meningkatkan potensi kekambuhan (Kaunang, Kanine dan Kallo, 2015). Salah satu penyebab keterlambatan pasien skizofrenia datang ke pelayanan kesehatan jiwa untuk melakukan kontrol rutin dan melakukan pengobatan adalah jarak tempat tinggal dengan pelayanan kesehatan jiwa. Hasil penelitan yang dilakukan di Rumah Sakit Khusus Jiwa (RSKJ) Soeprapto Provinsi Bengkulu tahun 2018 menyatakan bahwa terdapat hubungan yang signifikan antara jarak tempat tinggal dengan kepatuhan jadwal kontrol pada pasien skizofrenia (Sari, Giena dan Effendi, 2019). Namun hal tersebut tidak sejalan dengan penelitian yang dilakukan oleh Christiawati (2012), dimana secara statistik jarak tempat tinggal dengan

Email korespondensi: suar_chp@yahoo.com pelayanan kesehatan tidak signifikan mempengaruhi kepatuhan berobat. Petugas kesehatan berperan dalam mengontrol gejala kekambuhan skizofrenia (Yusuf, et al., 2019). Namun, hal tersebut tidak sejalan dengan penelitian yang dilakukan oleh (Kurnia, Tyaswati dan Abrori, 2015), dimana peran petugas kesehatan tidak memiliki pengaruh terhadap kekambuhan pasien skizofrenia di RSD dr. Soebandi Jember.

Berdasarkan hal tersebut di atas, peneliti tertarik untuk mengetahui lebih dalam mengenai faktor-faktor yang berhubungan dengan kekambuhan pada pasien skizofrenia di Kabupaten Badung.

\section{METODE PENELITIAN}

Penelitian ini merupakan penelitian observasi analitik dengan desain Crosssectional. Penelitian ini dilakukan di Poliklinik Jiwa Puskesmas I Abiansemal dan RSUD Mangusada, pada bulan Januari - Mei 2020. Sample dalam penelitian ini adalah keluarga dari pasien skizofrenia yang melakukan pengobatan di Poliklinik Jiwa Puskesmas I Abiansemal maupun RSUD Mangusada, yang berjumah 112 sample. Teknik sampling yang digunakan adalah Simple Random Sampling, dimana pengambilan sample dilakukan secara acak berdasarkan daftar pasien skizofrenia yang ke Poliklinik Jiwa Puskesmas I Abiansemal dan RSUD Mangusada. Sample dipilih dengan mempertimbangkan kriteria inklusi dan kriteria eksklusi. Adapun yang termasuk kriteria inklusi yaitu keluarga yang mengurus atau merawat pasien skizofrenia, sedangkan yang termasuk kriteria eksklusi yaitu keluarga yang 
mengurus atau merawat pasien skizofrenia yang tidak bersedia ikut serta dalam penelitian ini. Penelitian ini menggunakan data primer yang dikumpulkan melalui wawancara. Data dianalisis secara univariat, bivariat dengan uji statistik $C h i$ Square, dan multivariat menggunakan uji Regresi Logistik Binary. Penelitian ini telah disetujui oleh Komisi Etik Penelitian Fakultas Kedokteran, Universitas Udayana dengan nomor

862.UN14.2.2.VII.14/LT/2020.

\section{HASIL}

Gambaran Karakteristik Pasien Skizofrenia di Kabupaten Badung

Berdasarkan pada Tabel 1, pasien skizofrenia dengan umur $<40$ tahun berjumlah 37 pasien $(33,33 \%)$ dan $\geq 40$ tahun dengan jumlah 74 pasien $(66,67 \%)$. Pasien dengan jenis kelamin perempuan berjumlah 67 orang $(59,82 \%)$ dan yang berjenis kelamin laki-laki berjumlah 45 orang $(40,18 \%)$. Ditinjau dari tingkat pendidikan, pasien skizofrenia dengan pendidikan tinggi sebanyak 47 orang $(41,96 \%)$ dan pendidikan rendah (sebanyak 65 orang (58,05\%). Pasien skizofrenia sebagian besar tidak bekerja, yaitu berjumlah 84 orang (75\%) dan dengan status bekerja berjumlah 28 orang (25\%). Dilihat berdasarkan lamanya mengidap skizofrenia, sebagian besar pasien mengidap skizofrenia $\geq 5$ tahun, yaitu sebanyak 86 orang $(76,79 \%)$ dan pasien yang mengidap skizofrenia $<5$ tahun sebanyak 26 orang $(23,21 \%)$.

Tabel 1. Gambaran Karakteristik Pasien Skizofrenia di Kabupaten Badung

\begin{tabular}{|c|c|c|}
\hline Variabel & Frekuensi (n) & Proporsi (\%) \\
\hline \multicolumn{3}{|l|}{ Umur } \\
\hline$<40$ Tahun & 38 & 33,93 \\
\hline$\geq 40$ Tahun & 74 & 66,07 \\
\hline \multicolumn{3}{|l|}{ Jenis Kelamin } \\
\hline Perempuan & 67 & 59,82 \\
\hline Laki-laki & 45 & 40,18 \\
\hline \multicolumn{3}{|l|}{ Tingkat Pendidikan } \\
\hline \multicolumn{3}{|l|}{ Tinggi } \\
\hline \multirow[t]{2}{*}{ Rendah } & 47 & 41,96 \\
\hline & 65 & 58,05 \\
\hline \multicolumn{3}{|l|}{ Status Pekerjaan } \\
\hline \multicolumn{3}{|l|}{ Bekerja } \\
\hline \multirow[t]{2}{*}{ Tidak Bekerja } & 28 & 25,00 \\
\hline & 84 & 75,00 \\
\hline \multicolumn{3}{|l|}{ Status Ekonomi } \\
\hline Tinggi & 0 & 0 \\
\hline Rendah & 112 & 100,00 \\
\hline \multicolumn{3}{|c|}{ Lama Mengidap Skizofrenia } \\
\hline$<5$ Tahun & 26 & 23,21 \\
\hline
\end{tabular}

Email korespondensi: suar_chp@yahoo.com 
Gambaran Faktor Risiko Kekambuhan pada Pasien Skizofrenia di Kabupaten Badung

Tabel 2. Faktor Risiko Kekambuhan pada Pasien Skizofrenia di Kabupaten Badung

\begin{tabular}{lcc}
\hline \multicolumn{1}{c}{ Variabel } & $\begin{array}{c}\text { Frekuensi } \\
\text { (n) }\end{array}$ & $\begin{array}{c}\text { Proporsi } \\
\text { (\%) }\end{array}$ \\
\hline $\begin{array}{l}\text { Dukungan } \\
\text { Keluarga }\end{array}$ & 95 & 84,82 \\
$\quad$ Baik & 17 & 15,18 \\
$\quad$ Kurang & & \\
Kepatuhan & & \\
Minum & 73 & 65,18 \\
Obat & 39 & 34,82 \\
$\quad$ Patuh & & \\
$\quad$ Tidak & & \\
$\quad$ Patuh & & \\
Jarak & & \\
Tempat & & \\
Tinggal & & \\
Pasien & & \\
Skizofrenia \\
dengan
\end{tabular}

Faktor risiko kekambuhan pada pasien skizofrenia yag diteliti dalam penelitian ini adalah dukungan keluarga, kepatuhan minum oat dan jarak tempat tinggak pasien skizofrenia dengan pelayanan kesehatan jiwa. Dukungan Keluarga dalam penelitian ini diukur menggunakan kuesioner dukungan Email korespondensi: suar_chp@yahoo.com keluarga yang berjumlah 24 pernyataan, yang terdiri dari dukungan emosional (6 pernyataan), dukungan informasi (6 pernyataan), dukungan instrumental (6 pernyataan), dan dukungan penilaian (6 pernyataan). Pernyataan-pernyataan tersebut dinyatakan dalam bentuk skala likert sebagai berikut, " 0 " menyatakan "Tidak pernah", "1" menyatakan "Jarang", "2" menyatakan "Sering", dan "3" menyatakan "Selalu". Skor tertinggi berjumlah 72, dan yang terendah adalah 0 . Dimana dikategorikan menjadi dua kategori, yaitu dukungan keluarga baik (skor $\geq 36$ ) dan dukungan keluarga kurang (skor <36). Berdasarkan Tabel 5.2 dapat diketahui bahwa sebagian besar pasien skizofrenia dengan dukungan keluarga baik, yaitu berjumlah 95 orang $(84,82 \%)$ dan pasien dengan dukungan keluarga kurang sebanyak 17 orang (15,18\%).

Kepatuhan minum obat pada pasien skizofrenia dalam penelitian ini diukur dengan menggunakan kuesioner Morisky Medication Adherence Skale (MMAS) yang terdiri dari 8 pernyataan, dengan kriteria " 0 " menyatakan "Ya" dan "1" menyatakan "Tidak". Skor tertingi berjumlah 8 dan terendah adalah 0. Dimana dikategorikan menjadi dua kategori, yaitu "Patuh" apabila skor $>4$, dan "Tidak Patuh" jika skor $\leq 4$. Berdasarkan Tabel 5.3 dapat dilihat bahwa pasien skizofrenia yang patuh minum obat sebanyak 73 orang $(65,18 \%)$ dan yang tidak patuh minum obat sebanyak 39 orang $(34,82 \%)$. 
Jarak tempat tinggal pasien skizofrenia dalam penelitian ini diukur berdasarkan jarak dari tempat tinggal pasien skizofrenia menuju ke pelayanan kesehatan jiwa (Poliklinik Jiwa Puskesmas I Abiansemal dan RSUD Mangusada) tempat pasien skizofrenia biasanya kontrol maupun mengambil obat. Dikategorikan menjadi dua kategori, yaitu "Dekat" jika jarak $\leq 5 \mathrm{~km}$, dan "Jauh" apabila jarak $>5$ km. Berdasarkan Tabel 5.4 pasien skizofrenia dengan jarak tempat tinggal yang dekat $(\leq 5 \mathrm{~km})$ dengan pelayanan kesehatan jiwa berjumlah 82 orang $(73,21 \%)$, dan pasien dengan jarak tempat tinggal yang jauh $(>5 \mathrm{~km})$ dengan pelayanan kesehatan jiwa sebanyak 30 orang $(26,79 \%)$.

\section{Gambaran Kekambuhan Pasien Skizofrenia di Kabupaten Badung}

Berdasarkan Tabel 3 diketahui bahwa sebagian besar pasien skizofrenia tidak kambuh, dengan jumlah 72 orang $(64,29 \%)$, dan pasien skizofrenia yang kambuh berjumlah 40 orang (35,71\%).

Tabel 3. Kekambuhan Pada Pasien Skizofrenia di Kabupaten Badung

\begin{tabular}{lcc}
\hline \multicolumn{1}{c}{ Variabel } & $\begin{array}{c}\text { Frekuensi } \\
\text { (n) }\end{array}$ & $\begin{array}{c}\text { Proporsi } \\
\text { (\%) }\end{array}$ \\
\hline Kekambuhan & & \\
Pasien & & \\
Skizofrenia & 72 & 64,29 \\
$\quad$ Tidak & 40 & 35,71 \\
$\quad$ Kambuh & & \\
Kambuh & & \\
\hline
\end{tabular}

Hubungan Faktor Risiko terhadap Kekambuhan pada Pasien Skizofrenia di Kabupaten Badung

Email korespondensi: suar_chp@yahoo.com
Berdasarkan Tabel. 4 diketahui bahwa proporsi terjadinya kekambuhan pada kelompok umur 40 tahun keatas tahun yaitu sebesar 40,54\%, dan 1,5 kali lebih berisiko mengalami kekambuhan dibandingkan dengan kelompok umur dibawah 40 tahun. Hasil uji statistik didapatkan nilai p sebesar 0,1369 (95\% CI 0,85-2,81), dimana hal tersebut menunjukkan bahwa umur tidak bermakna secara statistik terhadap kekambuhan pada pasien skizofrenia di Kabupaten Badung $(p>0,05)$. Proporsi pasien skizofrenia berjenis kelamin laki-laki yang mengalami kekambuhan dalam penelitian ini sebesar $31,11 \%$, dan laki-laki 1,2 kali lebih berisiko mengalami kekambuahn dibandingkan perempuan. Hasil uji statistik didapatkan nilai p sebesar 0,4047 (95\% CI 0,47-1,36), yang berarti tidak terdapat hubungan antara jenis kelamin dengan kekambuhan pada pasien skizofrenia $(\mathrm{p}>0,05)$.

Dilihat berdasarkan tingkat pendidikan pasien skizofrenia, diketahui bahwa proporsi pasien skizofrenia dengan pendidikan rendah yang mengalami kekambuhan sebesar 49,23\% dan 2,9 kali lebih berisiko mengalami kekambuhan dibandingkan dengan pasien skizofrenia yang berpendidikan tinggi. Hasil uji statistik menunjukkan nilai $p$ sebesar 0,0004 (95\% CI 1,47-5,69), yang berarti terdapat hubungan antara tingkat pendidikan dengan kekambuhan pada pasien skizofrenia di Kabupaten Badung. Proporsi pasien skizofrenia dengan status tidak bekerja yang mengalami kekambuhan sebesar 44,05\%, dan 4,1 kali lebih berisiko mengalami kekambuhan dibandingkan dengan pasien skizofrenia 
yang bekerja. Uji statistik menunjukkan hasil nilai $\mathrm{p}$ sebesar 0,0014 (95\% CI 1,3712,30). Hal ini menunjukkan bahwa terdapat hubungan antara status pekerjaan dengan kekambuhan pada pasien skizofrenia di Kabupaten Badung. Hubungan status ekonomi dengan kekambuhan pada pasien skizofrenia di Kabupaten Badung, tidak dapat dilakukan analisis data untuk mengetahui hubungan kedua variabel tersebut. Hal tersebut dikarenakan $100 \%$ pasien skizofrenia dalam penelitian ini dengan status ekonomi rendah. Berdasarkan lamanya mengidap skizofrenia, dapat diketahui proporsi pasien skizofrenia yang mengidap skizofrenia lebih dari 5 tahun yang mengalami kekambuhan sebesar $38,37 \%$ dan 1,4 kali lebih berisiko mengalami kekambuhan dibandingkan dengan pasien skizofrenia yang mengidap skizofrenia kurang dari 5 tahun. Hasil uji statistik didapatkan hasil nilai $\mathrm{p}$ sebesar 0,2857 (95\% CI 0,72-2,83), yang berarti bahwa secara statistik tidak terdapat hubungan antara lama mengidap skizofrenia dengan kekambuhan pada pasien skizofrenia di Kabupaten Badung.

Proporsi pasien skizofrenia dengan dukungan keluarga kurang yang mengalami kekambuhan sebesar 58,82\%, dan 1,9 kali lebih berisiko mengalami kekambuhan dibandingkan dengan pasien skizofrenia dengan dukungan keluarga baik. Hasil uji statistik didapatkan nilai $p$ sebesar 0,0308 (95\% CI 1,13-3,06), dimana hal tersebut berarti secara statistik terdapat hubungan antara dukungan keluarga dengan kekambuhan pada pasien skizofrenia di Kabupaten Badung. Pasien skizofrenia yang tidak patuh minum obat yang mengalami kekambuhan sebesar $51,28 \%$, dan 1,9 kali lebih berisiko mengalami kekambuhan dibandingkan dengan pasien skizofrenia yang patuh minum obat. Hasil uji statistik menunjukkan nilai p sebesar 0,0120 (95\% CI 1,16-3,03), dimana hal tersebut berarti secara statistik kepatuhan minum obat berhubungan dengan kekambuhan pada pasien skizofrenia di Kabupaten Badung. Proporsi pasien skizofrenia dengan jarak tempat tinggal yang jauh dengan pelayanan kesehatan jiwa yang mengalami kekambuhan sebesar 20,00\%. Pasien skizofrenia yang jarak dari tempat tinggalnya dekat dengan pelayanan kesehatan jiwa 50\% lebih rendah mengalami kekambuhan dibandingkan dengan pasien skizofrenia yang jarak dari tempat tinggalnya menuju ke pelayanan kesehatan jiwa yang jauh. Berdasarkan uji statistik didapatkan nilai $\mathrm{p}$ sebesar 0,0358 (95\% CI 0,23 - 1,03 ). Hal tersebut menunjukkan tidak terdapat hubungan antara jarak tepat tinggal pasien skizofrenia dengan pelayanan kesehatan jiwa.

Tabel 4. Hubungan Karakteristik Individu terhadap Kekambuhan Pasien Skizofrenia di Kabupaten Badung

\begin{tabular}{lccccccc}
\hline & \multicolumn{5}{c}{ Kekambuhan pada Pasien Skizofrenia } \\
\cline { 2 - 7 } Variabel & $\begin{array}{c}\text { Tidak } \\
\text { Kambuh } \\
(\mathbf{n}=\mathbf{7 2})\end{array}$ & $\begin{array}{c}\text { Kambuh } \\
(\mathbf{n}=\mathbf{4 0 )}\end{array}$ & Frekuensi & $\mathbf{P}$ & PR & $\mathbf{9 5 \%}$ CI \\
\hline Umur & & & & 0,1369 & 1,54 & $0,85-2,81$
\end{tabular}

Email korespondensi: suar_chp@yahoo.com 


$\begin{array}{cccc}<40 \text { Tahun } & 28 & 10 & 38 \\ & (73,68 \%) & (26,32 \%) & (100 \%) \\ \geq 40 \text { Tahun } & 44 & 30 & 74 \\ & (59,46 \%) & (40,54 \%) & (100 \%)\end{array}$

Jenis Kelamin

Perempuan

Laki-laki

$\begin{array}{ccc}41 & 26 & 67 \\ (61,19 \%) & (38,81 \%) & (100 \%) \\ 31 & 14 & 45 \\ (68,89 \%) & (31,11 \%) & (100 \%)\end{array}$

Tingkat Pendidikan

Tinggi

39

8

$(82,98 \%)$

$(17,02 \%)$

47

Rendah

33

32

$(50,77 \%)$

$(49,23 \%)$

$(100 \%)$

65

Status Pekerjaan

Bekerja

25

$(89,29 \%)$

3

Tidak Bekerja

$$
47
$$

$(10,71 \%)$

$(100 \%)$

$(55,95 \%) \quad(44,05 \%) \quad(100 \%)$

Status Ekonomi

Tinggi

Rendah

$$
\begin{gathered}
0 \\
(0 \%)
\end{gathered}
$$

0

$(0 \%)$

0

72

40

$(0 \%)$

$(64.29 \%)$

(35.71)

112

$(100 \%)$

\section{Lama Mengidap}

Skizofrenia

$<5$ Tahun

19

$(73,08 \%)$

7

$(26,92 \%)$

$0,4047 \quad 1,25$

$0,74-2,12$

$\geq 5$ Tahun

53

33

$(61,63 \%)$

$(38,37 \%)$

$0,0308 \quad 1,86$

$1,13-3,06$

Dukungan Keluarga

Baik

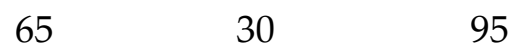

Kurang

$\begin{array}{ccc}(68,42 \%) & (31,58 \%) & (100 \%) \\ 7 & 10 & 17\end{array}$

$$
(41,18 \%) \quad(58,82 \%) \quad(100 \%)
$$

$$
0,0120 \quad 1,87 \quad 1,16-3,03
$$

\section{Obat}

Patuh

53

20

73

Tidak Patuh

$$
(72,60 \%)
$$

$(27,40 \%)$

$(100 \%)$

$\begin{array}{lll}19 & 20 & 39\end{array}$

$$
(48,72 \%)
$$

$(51,28 \%)$

(100\%)

Jarak Tempat Tinggal dengan Pelayanan Kesehatan Jiwa

Dekat

$\begin{array}{ccc}48 & 34 & 82 \\ (58,54 \%) & (41,46 \%) & (100 \%)\end{array}$

Email korespondensi: suar_chp@yahoo.com 
Jauh

Analisis Faktor-faktor yang Berhubungan dengan Kekambuhan pada Pasien Skizofrenia di Kabupaten Badung

Analisis multivariat faktor-faktor yang berhubungan dengan kekambuhan pada pasien skizofrenia di Kabupaten

Tabel 5. Analisis Multivariat Faktor-faktor yang Berhubungan dengan Kekambuhan pada Pasien Skizofrenia di Kabupaten Badung

\begin{tabular}{lcccc}
\hline & \multicolumn{4}{c}{ Model Akhir } \\
\cline { 2 - 5 } Variabel & OR & p & \multicolumn{2}{c}{ 95\% CI for OR } \\
Dukungan Keluarga \\
$\begin{array}{llll}\text { Baik } \\
\text { Kurang }\end{array}$ & 6,25 & 0,014 & 1,44 & Upper \\
\hline
\end{tabular}

Kepatuhan Minum Obat

Patuh

Tidak Patuh

6,59

0,001

2,13

20,45

\begin{tabular}{|c|c|c|c|c|}
\hline \multicolumn{5}{|c|}{ al Pasien Skizofrenia dengan Pelayanan Kesehatan Jiwa } \\
\hline $\begin{array}{l}\text { Dekat } \\
\text { Jauh }\end{array}$ & 0,29 & 0,049 & 0,08 & 0,99 \\
\hline
\end{tabular}

\section{Umur}

$<40$ Tahun

$\geq 40$ Tahun

1,07

0,900

0,35

3,28

Jenis Kelamin

Laki-laki

Perempuan

0,31

0,042

0,10

0,96

Tingkat Pendidikan

Tinggi

Rendah

8,88

0,000

2,60

30,33

\section{Status Pekerjaan}

Bekerja

Tidak

6,31

0,024

1,28

31,08

Bekerja

\section{Lama Mengidap Skizofrenia}

$$
<5 \text { Tahun 2,02 }
$$

0,312

0,52

7,85

Email korespondensi: suar_chp@yahoo.com 
Berdasarkan hasil analisis multivariat pada Tabel. 5, dapat diketahui bahwa secara statistik faktor-faktor yang berhubungan dengan kekambuhan pada pasien skizofrenia di Kabupaten Badung yaitu, dukungan keluarga $(\mathrm{p}=0,014 ; \mathrm{OR}=$ 6,$2 ; 95 \%$ CI : 1,44 - 27,12), kepatuhan minum obat $(p=0,001 ; O R=6,6 ; 95 \% C I$ : 2,13 -20,45), jarak tempat tinggal pasien skizofrenia dengan pelayanan kesehatan jiwa ( $p=0,049$; OR $=0,3 ; 95 \%$ CI :0,08 $0,99)$, jenis kelamin $(p=0,042 ; O R ; 0,3 ; 95 \%$ $\mathrm{CI}: 0,10-0,96)$, tingkat pendidikan $(\mathrm{p}=$ 0,000; OR = 8,9; 95\% CI : 2,60 - 30,33 ) dan status pekerjaan $(\mathrm{p}=0,024 ; \mathrm{OR}=6,3 ; 95 \%$ CI : 1,28 - 31,08 ). Dimana berdasarkan uji statistik faktor yang paling berhubungan atau berpengaruh terhadap kekambuhan pada pasien skizofrenia di Kabupaten Badung adalah tingkat pendidikan rendah dengan OR sebesar 8,9 kali lebih berisiko mengalami kekambuhan pada pasien yang berpendidikan rendah, dengan nilai $p$ sebesar 0,000 (95\% CI 2,60-30,33).

\section{DISKUSI}

\section{Faktor-faktor yang Berhubungan dengan} kekambuhan pada Pasien Skizofrenia di Kabupaten Badung

\section{Karakteristik Pasien Skizofrenia}

Karakteristik pasien skizofrenia yang diukur dalam penelitian ini yaitu umur, jenis kelamin, tingkat pendidikan, status pekerjaan, dan lama mengidap skizofrenia. Ditinjau berdasarkan umur, sebagian besar pasien skizofrenia di Kabupaten Badung yang menjadi sample dalam penelitian ini berumur 40 tahun keatas, dengan proporsi sebesar 66,07\%. Rata-rata umur pasien skizofrenia yang menjadi sample dalam penelitian ini adalah 46 tahun, dengan umur terkecil 26 tahun dan terbesar 75 tahun. Distribusi umur pasien skizofrenia terbanyak berada pada kisaran umur 37 tahun. Berdasarkan pada penelitian yang dilakukan oleh Sari dan Sirna (2015), umumnya skizofrenia pertama kali menyerang umur 15 sampai 30 tahun, namun berkembang ketika usia seseorang memasuki 40 tahun. Berdasarkan analisis bivariat, pasien skizofrenia dengan umur 40 tahun ke atas cenderung tidak mengalami kekambuhan (59,46\%). Berdasarkan uji statistik Chi Square, tidak terdapat hubungan yang bermakna antara umur dengan kekambuhan pada pasien skizofrenia di Kabupaten Badung. Hal tersebut sejalan dengan penelitian yang dilakukan oleh Schwarz et al. (2012), yang menyatakan bahwa umur tidak berhubungan dengan kekambuhan skizofrenia ( $\mathrm{p}=0,232)$. Hasil penelitian serupa pula didapatkan dalam penelitian (Erlina, Soewadi dan Pramono, 2010), dimana umur tidak memiliki hubungan yang signifikan tehadap kekambuhan pada pasien skizofrenia ( $p=0,683)$.

Pasien skizofrenia dalam penelitian ini sebagian besar berjenis kelamin perempuan dengan proporsi sebesar $59,82 \%$. Berdasarkan analisis bivariat, pasien skizofrenia yang berjenis kelamin laki-laki sebagian besar tidak mengalami kekambuhan (68,89\%). Maka dari itu hasil uji statistik Chi Square menyatakan tidak terdapat hubungan yang signifikan antara 
jenis kelamin dengan kekambuhan pada pasien skizofrenia di Kabupaten Badung. Hal tersebut didukung oleh penelitian yang dilakukan oleh Setiati, DW dan Suryawati (2017), yang menyatakan bahwa secara statistik tidak terdapat hubungan yang antara jenis kelamin dengan kekambuhan penderita skizofrenia. Hasil penelitian ini sejalan pula dengan penelitian Nofriyanto (2018), yang menyatakan tidak terdapat hubungan yang signifikan antara karakteristik jenis kelamin dengan frekuensi kekambuhan pada pasien skizofrenia di poliklinik Rumah Sakit Jiwa Grhasia Yogyakarta.

Proporsi pasien skizofrenia di Kabupaten Badung dengan pendidikan rendah sebesar $58,05 \%$. Hal tersebut sejalan dengan penelitian yang dilakukan oleh Handayani et al. (2017), yang menyatakan bahwa sebesar $61 \%$ pasien skizofrenia dengan pendidikan rendah. Analisis bivariat menunjukkan pasien skizofrenia dengan pendidikan tinggi mapun rendah sebagian besar tidak mengalami kekambuhan. Berdasarkan hasil uji Chi Square, secara statistik terdapat hubungan yang signifikan antara tingkat pendidikan dengan kekambuhan pada pasien skizofrenia di Kabupaten Badung. Dimana, pasien skizofrenia dengan pendidikan rendah 2,9 kali lebih berisiko mengalami kekambuhan dibandingkan dengan pasien skizofrenia yang berpendidikan tinggi. Hasil penelitian ini didukung oleh penelitian yang dilakukan oleh (Setiati, Dw dan Suryawati, 2017), yang menyatakan bahwa pendidikan berhubungan dengan kekambuhan penderita skizofrenia dimana pasien skizofrenia dengan pendidikan

Email korespondensi: suar_chp@yahoo.com rendah memiliki risiko 1,25 kali lebih besar dibandingkan dengan pasien skizofrenia yang berpendidikan tinggi. Hal tersebut dikarenakan pasien skizofrenia dengan tingkat pendidikan rendah cenderung kurang memperhatikan kualitas hidup sehat seperti mengelola stres, sehingga berpengaruh juga pada terapi pengobatan dan sebaliknya pasien dengan tingkat pendidikan tinggi cenderung lebih kritis terhadap kesehatan mereka (Kaunang, Kanine dan Kallo, 2015).

Dilihat berdasarkan status pekerjaan, $75 \%$ pasien skizofrenia dalam penelitian ini dengan status tidak bekerja. Hal ini didukung oleh penelitian yang dilakukan oleh Erlina, Soewadi dan Pramono (2010), dimana orang yang tidak bekerja kemungkinan mempunyai risiko 6,2 kali lebih besar menderita skizofrenia dibandingkan pasien skizofrenia dengan status bekerja. Hal tersebut dikarenakan orang yang tidak bekerja akan lebih mudah mengalami stres dan hal ini pula berhubungan dengan tingginya kadar hormon stres (kadar cathecholamine) yang mengakibatkan ketidakberdayaan pada psikis seseorang (Sudarmono et al., 2018). Analisis bivariat menunjukkan bahwa pasien skizofrenia dengan status bekerja maupun tidak bekerja sebagian besar tidak mengalami kekambuhan. Berdasarkan hasil uji Chi Square, secara statistik terdapat hubungan yang signifikan antara status pekerjaan dengan kekambuhan pada pasien skizofrenia, dan pasien skizofrenia dengan status tidak bekerja 4,1 kali lebih berisiko mengalami kekambuhan dibandingkan dengan pasien skizofrenia dengan status bekerja. Hasil penelitian ini 
didukung oleh penelitian yang dilakukan oleh Buckley (2013) yang menyatakan bahwa status pekerjan berhubungan dengan kekambuhan skizofrenia. Namun hasil penelitian ini tidak sejalan dengan penelitian yang dilakukan oleh Setiati, DW dan Suryawati (2017), secara statistik tidak terdapat hubungan antara pekerjaan dengan kekambuhan penderita skizofrenia, dan orang yang tidak bekerja berisiko mengalami kekambuhan sebesar 0,97 kali dibandingkan penderita skizofrenia yang bekerja.

Pasien skizofrenia dalam penelitian ini seluruhnya dengan status ekonomi rendah (100\%). Hal ini didukung oleh hasil penelitian yang dilakukan oleh (Erlina, Soewadi dan Pramono, 2010), yang menyatakan bahwa status ekonomi rendah mempunyai risiko 6 kali untuk mengalami skizofrenia dibandingkan status ekonomi tinggi. Hubungan status ekonomi dengan kekambuhan pada pasien skizofrenia di Kabupaten Badung dalam penelitian ini tidak dapat dilakukan analisis secara statistik. Hal tersebut dikarenakan data yang didapatkan dilapangan bias, dimana pasien skizofrenia dalam penelitian ini seluruhnya dengan status ekonomi rendah. Namun berdasarkan penelitian yang dilakukan oleh Setiati, Dw dan Suryawati (2017), yang menyatakan bahwa status ekonomi berhubungan dengan kekambuhan penderita skizofrenia, dan pasien skizofrenia dengan status ekonomi kurang dari UMR 1,4 kali lebih berisiko mengalami kekambuhan dibandingkan pasien skizofrenia yang memiliki status ekonomi lebih dari UMR. Sejalan dengan penelitian Puspitasari (2017), yang menyatakan bahwa status ekonomi Email korespondensi: suar_chp@yahoo.com merupakan salah satu faktor yang mempengaruhi kekambuhan pada pasien skizofrenia. Himpitan ekonomi memicu seseorang menjadi rentan dan terjadi berbagai peristiwa yang menyebabkan gangguan jiwa (Siti Zahnia, 2013).

Ditinjau berdasarkan lama mengidap skizofrenia, sebagian besar pasien skizofrenia dalam penelitian ini mengidap skizofrenia $\geq 5$ tahun (76,79\%). Rata-rata lama pasien mengidap skizofrenia yaitu 12 tahun, dan paling lama 46 tahun, serta lama mengidap paling sebentar adalah 1 tahun. Analisis bivariat menunjukkan bahwa pasien skizofrenia yang mengidap kurang dari 5 tahun maupun lebih dari sama dengan 5 tahun sebagian besar tidak mengalami kekambuhan. Hasil uji statistik Chi Square menunjukkan bahwa, secara statistik tidak terdapat hubungan antara lama mengidap skizofrenia dengan kekambuhan pada pasien skizofrenia di Kabupaten Badung, dan pasien skizofrenia yang mengidap skizofrenia lebih dari sama dengan 5 tahun 1,4 kali lebih berisiko mengalami kekambuhan dibadingkan pasien yang mengidap skizofrenia kurang dari 5 tahun. Hal tersebut sejalan dengan penelitian yang dilakukan oleh Kurnia, Tyaswati dan Abrori (2015), yang menyatakan bahwa pasien skizofrenia yang mengidap skizofrenia lebih dari 1 tahun 4,6 kali lebih berisiko mengalami kekambuhan dibandingkan dengan pasien yang mengidap skizofrenia kurang dari sama dengan 1 tahun. Kemungkinan hal tesebut dikarenakan banyak faktor diantaranya, terlambatnya penanganan atau pengobatan, pemberian antipsikotik yang kurang optimal, keterlibatan keluarga yang kurang, perawatan di masyarakat dan manajemen 
kasus yang buruk, sehingga pasien mempunyai prognosis yang mengakibatkan terjadinya kekambuhan (Kurnia, Tyaswati dan Abrori, 2015).

\section{Dukungan Keluarga}

Dukungan keluarga merupakan sikap, tindakan penerimaan keluarga terhadap anggota keluarganya, berupa dukungan informasi, dukungan penilaian, dukungan instrumental dan dukungan emosional (Friedman, 2010). Dukungan keluarga merupakan salah satu faktor penting dalam upaya meningkatkan motivasi seseorang, sehingga berpengaruh positif terhadap kesehatan psikologis (Fauziah dan Latipun, 2016). Keluarga menjadi salah satu faktor penentu keberhasilan penanganan skizofrenia (Christy dan Westa, 2019). Dalam penelitian ini sebagian besar pasien skizofrenia memiliki dukungan keluarga yang baik, dengan proporsi sebesar $84,82 \%$. Hal tersebut sejalan dengan hasil penelitian yang dilakukan oleh Prsityantama dan Ranimpi (2018), yang menyatakan proporsi pasien skizofrenia dengan dukungan baik sebesar 83,3\%. Hasil analisis bivariat memperlihatkan bahwa pasien skizofrenia dengan dukungan keluarga yang kurang cenderung mengalami kekambuhan (58,82\%). Sedangkan pasien skizofrenia dengan dukungan keluarga baik sebagian besar tidak mengalami kekambuhan $(68,42 \%)$.

Hasil penelitian ini menunjukkan secara statisik terdapat hubungan yang signifikan antara dukungan keluarga dengan kekambuhan pada pasien skizofrenia di Kabupaten Badung. Pasien skizofrenia dengan dukungan keluarga Email korespondensi: suar_chp@yahoo.com kurang 1,9 kali lebih berisiko mengalami kekambuhan dibandingkan dengan pasien skizofrenia dengan dukungan keluarga yang baik. Hasil penelitian ini sejalan dengan penelitian yang dilakukan oleh Dian, Herman P. L. Wungouw dan Legoh (2019), menyatakan bahwa terdapat hubungan antara dukungan keluarga dengan tingkat kekambuhan penderita gangguan skizofrenia di RSJ Naimata Kupang. Didukung pula oleh hasil penelitian yang dilakukan oleh Yuniar dan Pertami (2016), yang menyatakan bahwa dukungan keluarga memiliki hubungan yang signifikan dengan kekambuhan pasien skizofrenia rawat jalan, dimana responden yang tidak mendapat dukungan keluarga mempunyai resiko 8,7 kali lebih besar untuk mengalami kekambuhan dibandingkan dengan responden yang mendapat dukungan keluarga. Hal tersebut dikarenakan dukungan keluarga selama masa penyembuhan memberikan pengaruh yang besar terhadap pemulihan pasien (Sari dan Fina, 2011). Tempat terbaik bagi pasien skizofrenia adalah bersada di tengah-tengah keluarganya, diantaranya orang-orang yang dicintainya karena pasien skizofrenia membutuhkan perhatian, pengertian, dukungan, cinta dan kasih sayang (Minarni dan Sudagijono, 2015). Ketika keluarga dapat mengerti dan menerima kondisi pasien, hal ini dapat menjadi kunci dari keberhasilan pengobatan dan juga merupakan upaya pecegahan kekambuhan skizofrenia (Christy dan Westa, 2019). Dalam penelitian ini jenis dukungan keluarga yang paling berhubungan atau berpengaruh dengan kekambuhan pada 
pasien skizofrenia di Kabupaten badung berdasarkan analisis multivariat adalah dukungan penilaian. Dimana pasien skizofrenia dengan dukungan penilaian yang kurang 6,7 kali lebih berisiko mengalami kekambuhan dibandingkan dengan pasien skizofreniia dengan dukungan penilaian yang baik. Hal tersebut dikarenakan dukungan penilaian merupakan dukungan yang diberikan kepada pasien skizofrenia yang meliputi yang meliputi penghargaan positif atas hasil kerja yang dilakukan pasien, dorongan untuk maju, dan menengahi pemecahan masalah pertolongan, serta mengontrol an mengingatkan pasien skizofrenia minum obat (Rahmayani dan Hanum, 2018 ; Setiadi, 2011) Apabila pasien skizofrenia mendapat dukungan penilaian yang baik, maka pasien skizofrenia akan merasa lebih dihargai dan diterima oleh keluarganya sehingga pasien skizofrenia akan memiliki semangat hidup yang lebih besar dan dapat mengurangi terjadinya kekambuhan.

\section{Kepatuhan Minum Obat}

Kepatuhan minum obat merupakan hal penting yang harus diperhatikan dalam proses penyembuhan pasien skizofrenia. Ketidakpatuhan minum obat dapat menimbulkan dampak negatif seperti kekambuhan, dirawat kembali di rumah sakit dan percobaan bunuh diri (Higashi et al., 2013). Penelitian yang dilakukan oleh Kaunang, Kanine dan Kallo (2015), menyatakan sebesar 90,9\% pasien skizofrenia patuh minum obat. Berdasarkan hasil analisis univariat yang dilakukan dalam penelitian ini, sebagian besar pasien skizofrenia dinyatakan patuh minum obat dengan sebesar proporsi sebesar 65,18\%. Hasil analisis bivariat memperlihatkan bahwa pasien skizofrenia yang tidak patuh minum obat lebih cenderung mengalami kekambuhan (51,28\%). Sedangkan pasien skizofrenia yang patuh minum obat sebagian besar tidak mengalami kekambuhan $(72,60 \%)$. Kepatuhan minum obat secara statistik memiliki hubungan yang bermakna dengan kekambuhan pada pasien skizofrenia di Kabupaten Badung. Pasien skizofrenia yang tidak patuh minum obat 1,9 kali lebih berisiko mengalami kekambuhan dibandingkan dengan pasien skizofrenia yang patuh minum obat. Hasil penelitian ini didukungan oleh penelitian yang dilakukan oleh Maharani dan Hardisal (2017), yang menyatakan bahwa terdapat hubungan signifikan antara kepatuhan minum obat dengan kejadian kekambuhan penderita skizofrenia di Rumah Sakit Jiwa Tampan Provinsi Riau Tahun 2017. Penelitian serupa pula dilakukan oleh Mubin dan PH (2019), yang menyatakan terdapat hubungan yang signifikan antara kepatuhan minum obat dengan kekambuhan pasien (pvalue $=0,022<0,05$ ) dengan arah hubungan terbalik yang berarti bahwa semakin patuh pasien dalam minum obat maka dapat menurunkan kekambuhan pasien. Pasien skizofrenia yang tidak patuh minum obat akan memiliki risiko 11 kali mengalami kekambuhan dibandingkan dengan pasien skizofrenia yang patuh minum obat (Pratama, Syahrial dan Ishak, 2015).

\section{Jarak Tempat Tinggal Pasien Skizofrenia dengan pelayanan Kesehtan Jiwa}

Jarak tempat tinggal dengan pelayanan kesehatan jiwa dalam penelitian 
ini diukur berdasarkan jarak tempuh dari tempat tinggal pasien skizofrenia yang menjadi sample dalam penelitian ini menuju ke pelayanan kesehatan jiwa (Puskesmas 1 Abiansemal dan RSUD Mangusada). Rata-rata jarak tempuh pasien skizofrenia menuju pelayanan kesehatan jiwa adalah $8,4 \mathrm{~km}$. Jarak terjauh yang ditempuh pasien skizofrenia menuju pelayanan kesehatan jiwa yaitu $36 \mathrm{~km}$, dan jarak terdekat $0,4 \mathrm{~km}$. Rata-rata waktu tempuh dari tempat tinggal pasien skizofrenia menuju ke pelayanan kesehatan jiwa yaitu 15 menit, sedangkan waktu tempuh terlama yaitu 60 menit dan tercepat adalah 1 menit. Sebagian besar jenis transportsi yang digunakan oleh pasien skizofrenia menuju ke pelayanan kesehatan jiwa adalah kendaraan pribadi, dengan rata-rata biaya transportasi sebesar Rp.20.000,00. Hasil penelitian ini menunjukkan sebagian besar pasien skizofrenia dalam penelitian ini dengan jarak yang dekat dengan pelayanan kesehatan jiwa, dengan proporsi sebesar $73,2 \%$.

Analisis bivariat menunjukkan bahwa secara statistik tidak terdapat hubungan yang signifikan antara jarak tempat tinggal pasien skizofrenia dengan pelayanan kesehatan jiwa terhadap kekambuhan pada pasien skizofrenia di Kabupaten Badung. Dimana pasien skizofrenia dengan jarak tempat tingal yang jauh maupun dekat dengan pelayanan kesehatan jiwa lebih cenderung tidak mengalami kekambuhan. Hasil penelitian ini didukung oleh penelitian yang dilakukan oleh Christiawati (2012), menyatakan bahwa jarak tempat tinggal

Email korespondensi: suar_chp@yahoo.com dengan pelayanan kesehatan secara statistik tidak signifikan mempengaruhi kepatuhan berobat.

Faktor yang Paling Berhubungan dengan Kekambuhan pada Pasien Skizofrenia di Kabupaten Badung

Berdasarkan hasil analisis multivariat, didapatkan hasil akhir bahwa faktor-faktor yang memiliki hubungan yang bermakna dengan kekambuhan pada pasien skizofrenia di Kabupaten Badung yaitu, dukungan keluarga, kepatuhan minum obat, jarak tempat tinggal pasien skizofrenia dengan pelayanan kesehatan jiwa, jenis kelamin, tingkat pendidikan dan status pekerjaan.

Adapun faktor yang paling berhubungan atau berpengaruh dengan kekambuhan pada pasien skizofrenia di Kabupaten Badung adalah tingkat pendidikan, dimana pasien skizofrenia dengan tingkat pendidikan rendah 8,9 kali lebih berisiko mengalami kekambuhan dibandingkan dengan pasien skizofrenia dengan tingkat pendidikan yang tinggi. Hasil penelitian ini didukung oleh penelitian yang dilakukan oleh (Setiati, Dw dan Suryawati, 2017), yang menyatakan bahwa pasien skizofrenia dengan pendidikan rendah memiliki risiko 1,25 kali lebih besar dibandingkan dengan pasien skizofrenia yang berpendidikan tinggi. Hal tersebut dikarenakan pasien skizofrenia dengan tingkat pendidikan rendah cenderung kurang memperhatikan kualitas hidup sehat seperti mengelola stres, sehingga berpengaruh juga pada terapi pengobatan dan sebaliknya pasien dengan tingkat pendidikan tinggi cenderung lebih kritis terhadap kesehatan 
mereka (Kaunang, Kanine dan Kallo, 2015). Selain itu, pasien yang berpendidikan tinggi akan mampu menerapkan koping dalam upaya menyelesaikan masalah dan juga pengambilan keputusan dalam mencari pelayanan kesehatan untuk mencegah terjadinya kekambuhan daripada pasien dengan pendidikan yang rendah (Puspitasari, 2017).

\section{SIMPULAN}

Berdasarkan pemaparan di atas dapat disimpulkan bahwa sebagian besar pasien skizofrenia dalam penelitian ini tidak kambuh, dengan proporsi sebesar 64,29\%. Faktor-faktor yang berhubungan dengan kekambuhan pada pasien skizofrenia di Kabupaten Badung yaitu dukungan keluarga, kepatuhan minum obat, jarak tempat tinggal pasien skizofrenia dengan pelayanan kesehatan jiwa, jenis kelamin, tingkat pendidikan, dan status pekerjaan. Faktor yang paling berhubungan atau berpengaruh terhadap kekambuhan pada pasien skizofrenia di Kabupaten Badung adalah tingkat pendidikan $(\mathrm{OR}=8,9)$.

\section{SARAN}

Berdasarkan hasil penelitian yang dilakukan, maka saran yang bisa peneliti sampaikan yaitu, keluarga pasien hendaknya memperhatikan faktor-faktor yang dapat menyebabkan pasien skizofrenia mengalami kekambuhan agar kekambuhan pada pasien skizofrenia dapat dicegah. Bagi peneliti selanjutnya diharapkan untuk meneliti terkait faktor eksternal lainnya yang berhubungan dengan kekambuhan pada pasien skizofrenia.

\section{UCAPAN TERIMA KASIH}

Email korespondensi: suar_chp@yahoo.com
Peneliti mengucapkan terima kasih kepada pihak-pihak yang telah membantu penelitian ini, hingga penelitian ini dapat terselesaikan.

\section{DAFTAR PUSTAKA}

Amelia, D. R. \& Anwar, Z. (2013). Relaps pada Pasien Skizofrenia. Jurnal Ilmiah Psikologi Terapan, 01(01), hal. 53-65.

Aprilis, N. (2017). Faktor yang Berhubungan dengan

Kekambuhan Pasien Gangguan Jiwa di Rumah Sakit Jiwa Tampan Provinsi Riau Tahun 2016. Menara Ilmu, XI (77), hal. 108-116.

Buckley, P. F.(2013). Predictors of Relapse in the Year After Hospital Discharge Among Patients With Schizophrenia. Yearbook of Psychiatry and Applied Mental Health, 2013(1), hal. 406. Doi: 10.1016/j.ypsy.2012.06.040.

Cadge, C., Connor, C. \& Greenfield, S. (2019). University students' understanding and perceptions of schizophrenia in the UK: a qualitative study. BMJ Open Journal. Doi: http://dx.doi.org/10.1136/bmjopen -2018-025813.

Christiawati, A. (2012). Hubungan Cara Bayar, Jarak Tempat Tinggal dan Dukungan Keluarga dengan Kepatuhan Berobat Rawat Jalan Pasien Skizofrenia di RSJD Surakarta. Surakarta: Universitas Muhammadiyah Surakarta.

Christy, F. E. \& Westa, I. W. (2019). Hubungan Dukungan Keluarga dengan Frekuensi Kekambuhan 
Pasien Skizofrenia di Poliklinik Jiwa Rumah Sakit Umum Pusat Sanglah," Jurnal Medika Udayana, 8(9).

Dewi, I. A. I. U., Budhi, M. K. S. \& Sudirman, W. (2014). Analisis Ketimpangan Pembangunan antara Kabupaten/Kota Di Provinsi Bali. E-Jurnal Ekonomi dan Bisnis Universitas Udayana, 3(2), hal. 68-80. Tersedia pada: https://ojs.unud.ac.id/index.php/E EB/article/view/7494.

Dian, T., Herman P. L. Wungouw \& Legoh, D. (2019). Hubungan Dukungan Keluarga Dengan Tingkat Kekambuhan Penderita Gangguan Skizofrenia Di RSJ Naimata Kupang. Cendana Medical Journal, 16(2), hal. 30-34. Tersedia pada:

http://ejurnal.undana.ac.id/CMJ/a rticle/view/1501.

Dinas Kesehatan Kabupaten Badung. (2019). Data Pasien ODGJ dan Pasung 2018-2019.

Dinas Kesehatan Provinsi Bali (2019). Data Pasien Skizofrenia Provinsi Bali berdasarkan Kabupaten 2018.

Diny Rezki Amelia \& Anwar, Z. (2013). Relaps pada Pasien Skizofrenia. Jurnal Ilmiah Psikologi Terapan, 01(01), hal. 53-65. Doi: 10.22219/jipt.v1i1.1357.

Erlina, Soewadi \& Pramono, D. (2010). Determinan terhadap Timbulnya Skizofrenia pada Pasien Rawat Jalan di Rumah Sakit Jiwa Prof. $\mathrm{Hb}$ Saanin Padang Sumatera Barat. Berita Kedokteran

Email korespondensi: suar_chp@yahoo.com
Masyarakat, 26(2), hal. 71-80. Doi: https://doi.org/10.22146/bkm.3471

Fadli, S. M. \& Mitra, M. (2013). Pengetahuan dan Ekspresi Emosi Keluarga serta Frekuensi Kekambuhan Penderita Skizofrenia. Kesmas: National Public Health Journal, 7(10), hal. 466. Doi: 10.21109/kesmas.v7i10.6. Farkhah, L. \& Suryani, S. (2017). Faktor Caregiver dan Kekambuhan Klien Skizofrenia. Jurnal Keperawatan Padjadjaran, 5(1), hal. 37-46. Doi: 10.24198/jkp.v5n1.5.

Fatmawati, I. N. A. (2016). Faktor-Faktor Penyebab Skizofrenia (Studi Kasus Di Rumah Sakit Jiwa Daerah Surakarta). Surakarta: Universitas Muhamadiyah Surakarta.

Fauziah, S. \& Latipun. (2016). Hubungan Dukungan Keluarga dan Keberfungsian Sosial pada Pasien Skizofrenia Rawat Jalan. Jurnal Ilmiah Psikologi Terapan, 04(02), hal. 140-160. Doi: https://doi.org/10.22219/jipt.v4i2.3 609.

Friedman, M.M., Bowden, O \& Jones, M. (2010). Buku Ajar Keperawatan Keluarga: Riset, Teori, \& Praktik Edisi 5. Jakarta: EGC.

Gemilang, B. M. et al. (2017). Karakteristik Pasien Relapse pada Pasien Skizofrenia dan Faktor Pencetusnya di Rumah Sakit Jiwa ( RSJ ) Provinsi Bali. Jurnal Medika, 6 no 10, hal. 61-65.

Handayani, L. et al. (2017). Faktor Risiko Kejadian Skizofrenia di Rumah 
Sakit Jiwa Grhasia Daerah Istimewa Yogyakarta (DIY). Humanitas, 13(2), hal. 135. Doi: 10.26555/humanitas.v13i2.6069.

Hermiati, D. \& Harahap, R. M. (2018). Faktor Yang Berhubungan Dengan Kasus Skizofrenia. Jurnal Keperawatan Silampari, 1(1), hal. 78-92.

Doi: https://doi.org/10.31539/jks.v1i2.6. Herniyanti, R., Malini, H. \& Netrida. (2019). Pengaruh Terapi Murottal terhadap Perubahan Perilaku Kekerasan Klien Skizofrenia. Jurnal Keperawatan, 11(3), hal. 199208.

Doi: https://doi.org/10.32583/keperawa tan.v11i3.547.

Higashi, K. et al. (2013). Medication adherence in schizophrenia: Factors influencing adherence and consequences of nonadherence, a systematic literature review. Therapeutic Advances in Psychopharmacology, 3(4), hal. 200218.

Doi:

10.1177/2045125312474019.

Hothasian, J. M., Suryawati, C. \& Fatmasari, E. Y. (2019). Evaluasi Pelaksanaan Program Upaya Kesehatan Jiwa di Puskesmas Bandarharjo Kota Semarang Tahun 2018. Jurnal Kesehatan Masyarakat, 7(1), hal. 75-83. Tersedia pada: https://ejournal3.undip.ac.id/inde x.php/jkm/article/view/22848.

Hui, C. L. M. (2011). Relapse in Schizophrenia. Medical Bulletin, 16(5), hal. 8-9. Tersedia pada: http://www.fmshk.org/database/a rticles/03mb2_19.pdf.

Kaunang, I., Kanine, E. \& Kallo, V. (2015). Hubungan Kepatuhan Minum Obat dengan Prevalensi Kekambuhan pada Pasien Skizofrenia yang Berobat Jalan di Ruang Poliklinik Jiwa Rumah Sakit Prof Dr. V. L. Ratumbuysang Manado. Jurnal Keperawatan UNSRAT, 3(2), hal. 1-7. Tersedia pada:

https://ejournal.unsrat.ac.id/index .php/jkp/article/view/8196.

Kementrian Kesehatan RI. Riset Kesehatan Dasar 2018. Jakarta

Kurnia, F. Y. P., Tyaswati, J. E. \& Abrori, C. (2015). Faktor-faktor yang Mempengaruhi Kekambuhan pada Pasien Skizofrenia di RSD dr. Soebandi Jember. E-Jurnal Pustaka Kesehatan, 3(3), hal. 400407. Tersedia pada: https://jurnal.unej.ac.id/index.php /JPK/article/view/2998/2412.

Maharani, R. \& Hardisal. (2017). Faktor yang Berhubungan dengan Kekambuhan Penderita Skizofrenia di Rumah Sakit Jiwa Tampan Provinsi Riau. Menara Ilmu, 6(77), hal. 150-160.

Manalu, E. D. \& Siagian, N. D. Y. (2019). Faktor-Faktor yang Mempengaruhi Kepatuhan Pasien Gangguan Jiwa Melakukan Pengobatan Rutin ke Puskesmas Sidodadi Kecamatan Kota Kisaran Barat Kabupaten Asahan Tahun 2018. Jurnal Penelitian Kesmasy, 2(1), hal. 93-99. Doi: https://doi.org/10.36656/jpksy.v2i 1.171.

Email korespondensi: suar_chp@yahoo.com 
Minarni, L. \& Sudagijono, J. S. (2015). Dukungan Keluarga terhadap Perilaku Minum Obat pada Pasien Skizofrenia yang Sedang Rawat Jalan. Experientia: Jurnal Psikologi Indonesia, 3(2), hal. 13-22. Doi: https://doi.org/10.33508/exp.v3i2. 904.

Mubin, M. F. \& PH, L. (2019). Hubungan Kepatuhan Minum Obat Dengan Kekambuhan Pasien Skizofrenia Paranoid. Jurnal Farmasetis, 8(1), hal. 21-24. Doi: 10.32583/farmasetis.v8i1.493.

Mura, G. et al. (2012). Schizophrenia: from Epidemiology to Rehabilitation. Clinical Practice $\mathcal{E}$ Epidemiology in Mental Health, 8(1), hal. 52-66. Doi: 10.2174/1745017901208010052.

Nurjamil, D. \& Rokayah, C. (2019). Hubungan Antara Peran Keluarga dengan Kepatuhan Minum Obat Pasien Skizofrenia. Jurnal Keperawatan Jiwa, 5(1), hal. 53. Doi: 10.26714/jkj.5.1.2017.53-59.

Pratama, Y., Syahrial \& Ishak, S. (2015). Hubungan Keluarga Pasien terhadap Kekambuhan Skizofrenia di Badan Layanan Umum Daerah (Blud) Rumah Sakit Jiwa Aceh. Jurnal Kedokteran Syiah Kuala, 15(2), hal. 77-86. Tersedia pada: http://www.jurnal.unsyiah.ac.id/J KS/article/view/3258/3082.

Prsityantama, W. A. \& Ranimpi, Y. Y. (2018). Hubungan Dukungan Keluarga Dengan Tingkat Kekambuhan Penderita Skizofrenia di Kecamatan

Email korespondensi: suar_chp@yahoo.com
Kaliwungu Kabupaten Semarang. Jurnal Ilmiah Bidang Keperawatan dan Kesehatan Available, 1(2), hal. 17-26. Tersedia pada: http://jurnal.unw.ac.id:1254/index .php/ijnr/article/view/178/146.

Puspitasari, E. (2017). Faktor yang Mempengaruhi Kekambuhan Orang Dengan Gangguan Jiwa. Jurnal Ilmu Keperawatan, 1(November), hal. 58-62. Doi: http://dx.doi.org/10.32584/jpi.v1i2 .47 .

Sari, A. F., Giena, V. P. \& Effendi, S. (2019). Hubungan Dukungan Keluarga dan Jarak Tempat Tinggal dengan Kepatuhan Jadwal Kontrol Pasca Keluar Rumah Sakit pada Pasien Skizofrenia di Rumah Sakit Khusus Jiwa (Rskj) Soeprapto Provinsi Bengkulu Tahun 2018. Chmk Nursing Scientific Journal, 3(2), hal. 69-79. Tersedia pada: http://cyber-

chmk.net/ojs/index.php/ners/artic le/view/543/209.

Sari, D. K. \& Wardani, L. K. (2018). Efektifitas Pemberian Family Psychoeducation (FPE) terhadap Kekambuhan Penderita Skizofrenia di Kota Kediri. Medica Majapahit, 10(1), hal. 1-7.

Sari, H. \& Sirna, W. (2015). Faktor Predisposisi Penderita Skizofrenia di Poli Klinik Rumah Sakit Jiwa Aceh. Idea Nursing Journal, VI(2), hal. 12-20.

Sariah, A. E., Outwater, A. H. \& Malima, K. I. Y. (2014). Risk and protective factors for relapse among 
Individuals with Schizophrenia: A Qualitative Study in Dar es Salaam, Tanzania. BMC Psychiatry, 14(1), hal. 1-12. Doi: 10.1186/s12888-014-0240-9.

Schwarz, E. et al. (2012). Identification of blood-based molecular signatures for prediction of response and relapse in schizophrenia patients. Translational Psychiatry, hal. 1-9. Doi: 10.1038/tp.2012.3.

Setiati, E., Dw, S. \& Suryawati, S. (2017). Dukungan Sosial dan Ketaatan Pengobatan Dengan Kekambuhan Pasien Skizofrenia di Purworejo S. BKM Journal of Community Medicine and Public Health, 33(6), hal. 305-310.

Siringoringo, E. \& Haerati. (2018). FaktorFaktor Penyebab Kekambuhan pada Pasien Skizofrenia di Poliklinik Jiwa Rsud H. Andi Sulthan Dg. Radja Kabupaten Bulukumba. Jurnal Stikes Panrita Husada, 3(1), hal. 24-40. Doi: https://doi.org/10.37362/jkph.v3i1. 8.

Siti Zahnia, D. W. S. (2013). Kajian Epidemiologis Skizofrenia. 5(4), hal. $\quad 160 . \quad$ Tersedia pada:http://juke.kedokteran.unila. ac.id/index.php/majority/article/v iewFile/904/812.

Sudarmono et al. (2018). Faktor Risiko Kejadian Skizofrenia di Rumah Sakit Madani Palu. Jurnal Kolaboratif Sains, 1(1), hal. 540-550.

Doi: http://dx.doi.org/10.31934/jom.v1i 1.387.

Suparmi, Maisya, I. B. \& Lestari, H. (2019). Email korespondensi: suar_chp@yahoo.com
Jaminan Kesehatan Sebagai Solusi Mengatasi Hambatan Akses dan Biaya Dalam Pemanfaatan Pelayanan Kesehatan Ibu di Indonesia. Badan Litbangkes. Tersedia pada: http://www.healthpolicyplus.com /ns/pubs/1735917648_PBHealthIn suranceInd.pdf.

Susanti. (2019). Determinan Kekambuhan Pasien Gangguan Jiwa yang Dirawat Keluarga di Wilayah Kerja UPTD Puskesmas Suak Ribee Aceh Barat. Majalah Kesehatan Masyarakat Aceh (MaKMA), 2(1), hal. 99-109. Doi: http://dx.doi.org/10.32672/makma .v2i1.887.

Susila \& Suyatno. (2014). Metode Penelitian Epidemiologi. Yogyakarta: Bursa Ilmu.

Wahyudi, A. \& Fibriana, A. I. (2016). Faktor Resiko Terjadinya Skizofrenia (Studi Kasus di Wilayah Kerja Puskesmas Pati II). Public Health Perspective Journal, 1(1), hal. 1-12. Tersedia pada: https://journal.unnes.ac.id/nju/ind ex.php/phpj/article/download/775 $0 / 5394$.

Wahyuningrum, I. (2013). Hubungan Dukungan Keluarga dengan Durasi Kekambuhan pasien Skizofrenia di Rumah Sakit Jiwa Daerah DR. Amino Gondohutomo Semarang. Karya Ilmiah, hal. 1-6. Tersedia pada: http://112.78.40.115/ejournal/index.php/ilmukeperawat an/article/view/124/149.

Yuniar, D. \& Pertami, S. B. (2016). 
Arc. Com. Health Agustus 2021

p-ISSN 2302-139X e-ISSN 2527-3620

Kepatuhan Minum Obat Dan

Dukungan Keluarga terhadap

Kekambuhan Pasien Skizofrenia.

Media Informasi, 12(2), hal. 19-23.

Doi:https://doi.org/10.37160/bmi.

v12i2.44.

Yusuf et al. (2019). Kesehatan Jiwa:

Pendekatan Holistik dalam

Asuhan Keperawatan. Edisi 1.

Jakarta: Mitra Wacana Media.

Zahnia, S. \& Sumekar, D. W. (2016). Kajian

Epidemiologis Skizofrenia.

Majority, 5(4), hal. 160-166.

Tersedia pada:

http://juke.kedokteran.unila.ac.id/

index.php/majority/article/view/9

04/812.

Email korespondensi: suar_chp@yahoo.com 